\title{
A REVIEW OF THE SEMI-SOLID PROCESSING OF STEEL
}

\author{
H. V. Atkinson ${ }^{1^{*}}$, A. Rassili ${ }^{2}$ \\ ${ }^{1}$ Department of Engineering, University of Leicester, University Rd., Leicester, LE1 7RH, UK \\ hva2@le.ac.uk \\ ${ }^{2}$ PiMW (B56), University of Liège, Boulevard de Colonster, 4B-4000 Liège, Belgium. \\ a.rassili@ulg.ac.be
}

\begin{abstract}
Steel is a particularly challenging material to semi-solid process because of the high temperatures involved and the potential for surface oxidation. Here the experience of semi-solid processing will be reviewed and the current situation in relation to commercial application assessed. The review will include discussion of the range of potential steel materials which are amenable to thixoforming including thermodynamic prediction of suitable alloy compositions.
\end{abstract}

KEYWORDS: Steel, thixoforming, semi-solid processing, dies.

\section{INTRODUCTION}

In this Introduction, background history on the semisolid processing of steel will be given and major themes for the review drawn out.

Semi-solid processing involves forming in the semi-solid state between the solidus and the liquidus. The process was first discovered by Flemings and his group at MIT in the early 1970s [1]. For successful forming, the microstructure in the semi-solid state must consist of spheroids of solid in a liquid matrix. The material then behaves thixotropically i.e. when it is sheared it flows but when allowed to stand it thickens again. The forming processes based on this behaviour have therefore been christened thixoforming, thixoforging (when the solid fraction is high) and thixocasting (when the solid fraction is low). The Flemings group experimented at the pilot plant scale with rheocasting (i.e. forming in the semi-solid state direct from the cooling liquid metal rather than having an intermediate solidification step). They formed a series of steels including AISI 304 and $440 \mathrm{C}$ [e.g.2] but found that oxide inclusions tended to lead to variable mechanical properties. Aluminium casting alloys and magnesium alloys proved highly amenable to the process and in the 1980s there was extensive effort on the industrialisation of the thixoprocesses for light alloys, with the more challenging high temperature alloys moving into the background. In the early 1990s, a group based in Sheffield, UK, led by Kirkwood, Sellars and Kapranos, revived interest with a consortium of UK based companies including
Rolls Royce. The Sheffield equipment used a vertically upwards acting ram within a vacuum chamber (to avoid oxidation of the slug during heating) and a graphite die. Such a die would not be suitable for long production runs but was relatively cheap in comparison with tool steel dies and therefore suitable for an experimental programme. The Sheffield group saw the potential of ceramic dies for thixoforming high temperature alloys and patented this idea [3]. The Sheffield work compared results from spray formed materials [4] (a relatively expensive process) with the RAP (Recrystallisation and Partial Melting) process [5] which simply involved material in the conventionally cast and heavily deformed state for T15, M2 and H13 tool steels and 440C stainless steel, with encouraging results. The consortium then focussed on M2 tool steel for extensive trials, partly because it has a reasonably large freezing range $\left(>40^{\circ} \mathrm{C}\right)$ in comparison with stainless alloys, and partly because its high alloy content leads to a relatively low solidus. An example of the resulting gear toothed demonstrator is shown in Figure 1.

Modelling of the induction heating of the billet showed that heat was being lost from the corners of the billet making these parts resistant to deformation; this led to process improvements [7]. At the end of this consortium project in the early 1990s the main difficulty was that there was no commercial manufacturer of equipment for steel thixoforming and companies were not willing to take the risk on the developmental stage.

In parallel with the Sheffield work, the Thixoforming Unit at EFU in Germany led by Hirt was also aiming to

\footnotetext{
* Corresponding author: Department of Engineering, University of Leicester, University Rd., Leicester, LE1 7RH, UK, Tel: 00-44116- 2231019, Fax: 00-44-116-2522525, hva2@le.ac.uk
} 


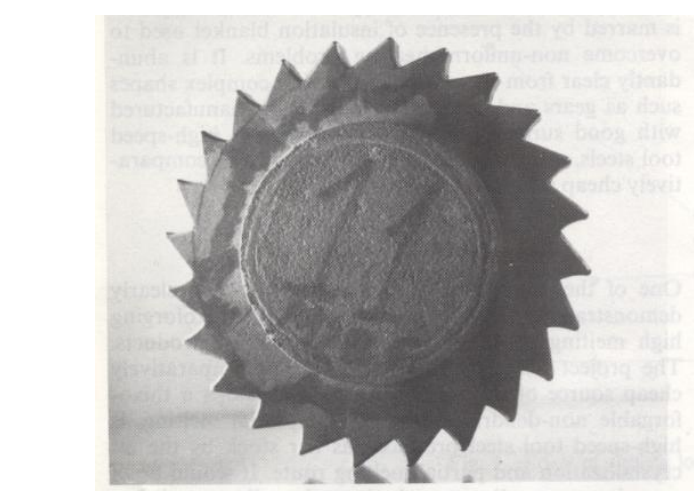

Figure 1: M2 tool steel demonstrator [6]

thixoform steels. It became clear that without the facility to shroud the billet during heating, the build up of oxide on the surface prohibited successful processing. A major collaborative project on thixoforming was initiated at RWTH Aachen and issues such as die longevity started to be explored. Work at Aachen [8] showed that, when thixoforming M2, the stresses induced in the die tool steel were several times the yield strength and therefore ceramic inserts were necessary. Meyer and Bleck (also at Aachen) [9] showed Differential Thermal Analysis (DTA) results for M2 and compared with the calculated results from a thermodynamic prediction package, techniques which become powerful in enabling amenable steels to be identified and characterised. At a 1997 conference, work was also presented highlighting that commercial wrought high speed steel bar could be thixoformed without any special treatment [10]. As we have progressed into the 2000s, major EU consortia ('THIXOCOMP' and COST 541 'THIXOSTEEL') and further work by a consortium based in Aachen have aimed to overcome the major barriers to exploitation. The themes in this review are: routes to thixoformable starting materials; identification of suitable steels; modelling of die fill and rheological property measurement; technology considerations; die development; properties of thixoformed products. Concluding remarks will then be given.

\section{ROUTES TO THIXOFORMABLE STARTING MATERIALS}

As identified above [2], the Flemings group used rheocasting to obtain thixotropic material. However, this requires the facilities to melt steel and hold it in the liquid state; many university laboratories have not had facilities on this scale available. Rheo-routes are preferable as there is an energy saving relative to the routes where there is an intermediate solidification step; this saving is particularly crucial for a high melting temperature such as steel. Routes where molten steel has been treated include the following. A group based in Seoul has produced stainless steel billets by Magneto Hydrodynamic (MHD) stirring and shown excellent microstructures [11]. The University of Science and Technology in Beijing has also electromagnetically stirred steels (in this case spring steels and stainless steel) and then rheorolled the semi-solid slurry [12].
There is liquid macrosegregation but this is being reduced through grooved rolling. At CRM in Liege in Belgium they have developed a specially designed hollow jet nozzle for continuous casting which allows powder injection and a low superheat to be combined to obtain a globular structure in the core of a continuously cast steel billet [13].

Various workers [14-17] are investigating the use of a cooling slope (similar to the New Rheocasting-NRCprocess or the work of Haga and co-workers [18,19]) with some success. Vibratory casting has also been used [20], including to obtain functionally graded material based on hydroxyapatite and 316L stainless steel [21].

There has been interest in whether steel can be thixoformed in the standard state in which it is received from a steel supplier. Bulte and Bleck [22] compared the microstructure after quenching from the semisolid state for 100Cr6 rolled bar, laboratory cast billet and laboratory cast billet with liquid core reduction. They found no significant difference and therefore suggest primary as-cast billet can be used. Omar and co-workers $[23,24]$ have demonstrated that the high performance steel HP9/4/30, which is very difficult to form by other routes, can be successfully thixoformed in the assupplied state. Note that in the as-supplied state the material is already recrystallised and therefore this route does not fit with the 'classical' solid state routes of RAP and SIMA (Strain Induced Melt Activated).

\section{IDENTIFICATION OF SUITABLE STEELS}

The original approach to identifying suitable steels involved examining the phase diagram. This showed that low alloy, low carbon steels had narrow solidus-liquidus ranges and therefore process control was likely to be difficult. Work therefore focussed on high alloy, high carbon compositions, which also tend to be the compositions which are the most difficult to work by conventional means.

As mentioned in the Introduction, the approach of combining experimental results from Differential Thermal Analysis (DTA) alongside thermodynamic prediction was then developed.

Kazakov [25] identified parameters for the liquid fraction versus temperature curve for alloys to be suitable for thixoforming. These have been adapted for steels [26]:

$\square$ The solidus and liquidus temperatures, $T_{S}$ and $T_{L}$, which must be as low as possible;

$\square$ The temperature at $50 \%$ liquid, $\mathrm{T}_{50 \%}$, which must be as low as possible;

$\square$ The melting interval, $\mathrm{T}_{\mathrm{L}}-\mathrm{T}_{\mathrm{S}}$, which must be as large as possible;

$\square$ The semimelting interval, $\mathrm{T}_{50 \%}-\mathrm{T}_{\mathrm{S}}$, which is of interest as it approximates to the thixoforming window;

$\square$ The slope at 10 and $50 \%$ liquid, $(\mathrm{df} / \mathrm{dT})_{10 \%}$ and $(\mathrm{df} / \mathrm{dT})_{50 \%}$, which must be as low as possible to ensure a small sensitivity of liquid fraction to temperature. 
Figures 2 and 3 show the prediction curves for a conventional steel $100 \mathrm{Cr} 6$ and a steel where the composition has been modified specifically for thixoforming and which is produced by Ascometal [27].

$100 \mathrm{Cr} 6$

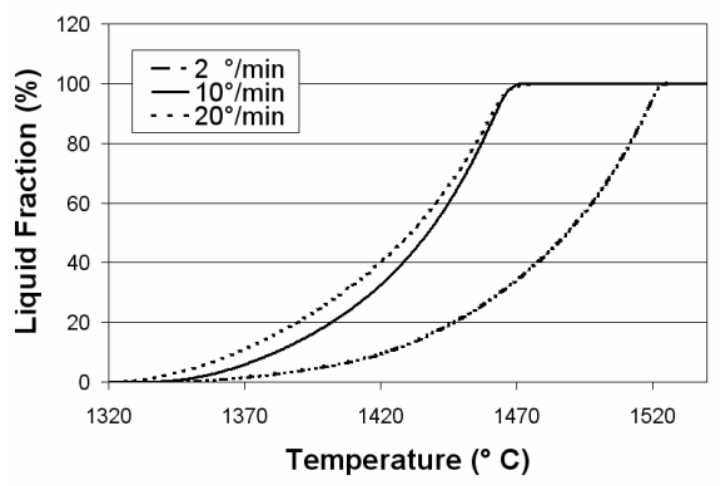

Figure 2 Thermodynamic prediction of liquid fraction versus temperature for conventional steel 100Cr6 [27]. C38 modif 2

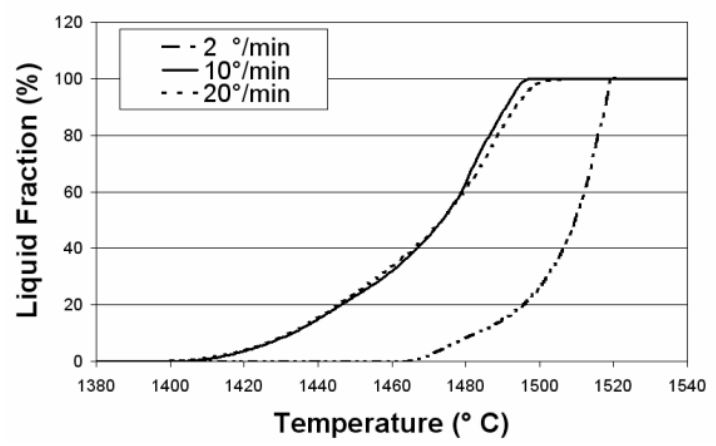

Figure 3 Thermodynamic prediction of liquid fraction versus temperature for a modified steel [27].

The modified alloys have a lower solidus temperature and a wider process temperature range [28]. However, the effect on resulting mechanical properties must also be carefully weighed.

Puttgen and Bleck [29] have carried out extensive DTA experiments, showing that the cold work tool steel X210CrW12 and the tool steel HS 6-5-3 have a wide semi-solid area (due to the dissolution of different carbides) but a range of other steels have much narrower semi-solid regimes. The bearing steel $100 \mathrm{Cr} 6$ is also highly suitable. This steel and X210CrW12 have therefore been extensively investigated in terms of the phase formation during processing [30]. Hallstedt et al. [31] have also used thermodynamic prediction, suggesting that important criteria are the slope at 50\% liquid and the temperature ranges between $40 \%$ liquid and $60 \%$ for thixocasting and $20 \%$ and $40 \%$ for thixoforging.

$\mathrm{Li}$ et al. [32] have identified how the inverse peritectic reaction can lead to spheroidisation in stainless steels in the semi-solid state. They argue that spheroidisation will always occur in an alloy with a peritectic reaction independent of the morphology in the solid state. They have named this phenomenon Inverse Peritectic Induced Spheroidisation (IPIS) (Figure 4).

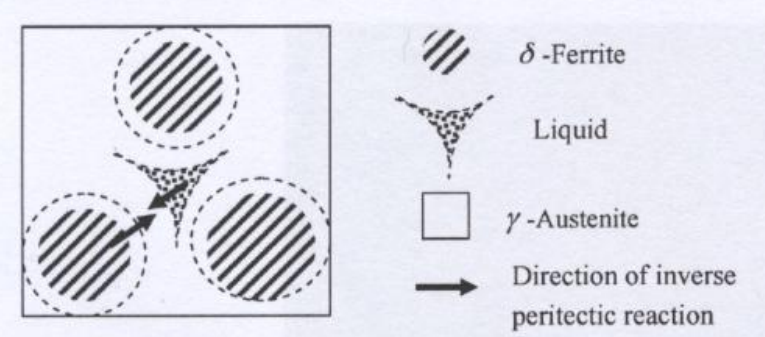

Figure 4 Mechanism of spheroidisation resulting from inverse peritectic reaction during partial remelting [32].

\section{MODELLING OF DIE FILL AND RHEOLOGICAL PROPERTY MEASUREMENT}

Modelling of semi-solid processing has been reviewed by Atkinson [33]. The high temperatures involved with steels make the experiments particularly challenging. Modigell et al. [34] have developed a high temperature Couette rheometer to analyse flow properties up to $1500^{\circ} \mathrm{C}$ and have characterised $\mathrm{X} 210 \mathrm{CrW} 12$. Cezard et al. [35] have derived input parameters for their finite element simulation using Forge 2 software from successive comparisons of the simulated loaddisplacement curves with experimental ones for compression tests on steel semi-solid at different temperatures. The constitutive equation is based on the micro-macro approach. Omar et al. [36] have also obtained viscosity-shear rate relationships from loaddisplacement curves. Hot compression is used to obtain flow stress curves but only around the solidus temperature [37]. Shimahara et al. [38] have designed a special cyclinder sample with a shell to avoid the problem of collapse of the sample during hot compression as liquid develops. At temperatures just below and just above the solidus, Solek et al. [39] and Kang et al. [40] have carried out experiments with a Gleeble simulator to characterise rheological properties. At present modelling of die fill is not well developed because of the difficulties with obtaining experimental parameters but the principles should be similar to those for modelling semi-solid die fill in general [33].

\section{TECHNOLOGY CONSIDERATIONS}

The industrial development of steel thixoforming must be accompanied by knowledge and control of the various parameters for the process: the identification of the steel grades; the homogeneous high-temperature heating of the slug before deformation; conception or re-conception of the part to adapt it to the process; the parameters for forming including ram velocity profile, hold time and pressure at the end of the stroke, die temperature, die material. The handling system is also important; it allows the slug to be transferred, in the semi-solid state, between the heating zone and the tooling and to evacuate the thixoformed part so as to ensure the quality heat treatment of the part. All these aspects contribute to 
achieving a cost for the finished part which is competitive with more conventional processes [41].

Industrial developments include: non-contact temperature measurement during heating [42]; the use of fuzzy logic to control the heating [43]; optimising the induction coil geometry [44]; prediction of thermal losses during transport and after insertion into the die [45]; a device on the hydraulic press to counteract the decrease of the punch speed in the final stages of the stroke [46]; automated handling and industrial vision systems $[47,48]$.

\section{DIE DEVELOPMENT}

Die development is one of the biggest challenges in semi-solid processing steel; the dies tend to wear excessively because of the high temperatures and temperature changes involved, and also because of attack by the semi-molten steel. A series of different potential solutions have been investigated including: oxide PVD coatings on TZM (a Mo-based alloy) [49]; PACVD alumina films on hot working steel [50]; ceramic inserts $\left(\mathrm{Si}_{3} \mathrm{~N}_{4}, \mathrm{ZrSiO}_{4}\right)$ in a hot working steel shrink ring [51]. In work at Aachen [52], three types of materials have been compared: thin film PVD and PACVD; thermally sprayed thick coatings and bulk ceramic materials. The results showed that the behaviour was sensitive to the stresses at the surface of the die and therefore the die should be made of different materials in different positions.

Gas pressure sintered $\mathrm{Si}_{3} \mathrm{~N}_{4}$ is an effective die material for low die temperatures $\left(300-400^{\circ} \mathrm{C}\right)$ because of its high strength and outstanding thermal shock resistance [53]. At higher temperatures $\left(1200^{\circ} \mathrm{C}\right)$ high purity dense alumina is needed [53]. Bobzin et al. [54] examined the most effective form of alumina coating, showing that using the reactive pulsed PVD process it was possible to stabilize gamma-alumina on steel substrates and obtain excellent performance for thixoforging X210CrW12 and $100 \mathrm{Cr} 6$.

Laser glazing of tool steels has been investigated [55] but the beneficial surface layer did not persist at the temperatures involved for thixoforming steels. Birol $[56,57]$ has investigated the performance of nickelbased IN617 and of a CrNiCo alloy as die materials but with limited success. He also showed that an increase in the die bulk temperature from $450^{\circ} \mathrm{C}$ to $550^{\circ} \mathrm{C}$ gives a very favourable effect from a thermal fatigue point of view [58].

Puttgen et al. [59] have investigated the thermal shock loading on coated samples, indicating a clear dependence on the base material. The combination of $\mathrm{Ni}$ alloy 2.4631 and HVOF gave the best results.

A self-heating ceramic tool (sintered alumina with a heating coil) has been successfully developed by Muenstermann et al. [60] for thixoextrusion of $\mathrm{X} 210 \mathrm{CrW} 12$. Almost isothermal processing can be achieved.

Overall, there are encouraging results for die development. What is needed now is cost comparison information allied with long life tests to identify the most economic solutions.

\section{PROPERTIES OF THIXOFORMED PRODUCTS}

Puttgen et al. [61] have summarised the experience of various workers in thixoforming finished parts including a catalogue of the defects and giving suggestions for how to avoid them. Runs with hundreds of parts in them have been produced with various alloys but reproducibility has tended to be poor. They conclude that efforts are still needed to produce defect-free components in serial production at competitive costs. Solid-liquid segregation, in particular, causes major variations in carbon content through a component and thus inhomogeneous mechanical properties. Parts with great hardness and wear resistance can be produced [6264] but there is a tendency to brittleness [65]. There is clearly further work to be done on optimising heat treatment [66].

\section{CONCLUSIONS}

Semi-solid processing of steel is a very active area for research and development. The main challenges now are with die protection from degradation and with industrialisation. Considerable progress has been made.

\section{ACKNOWLEDGEMENT}

The authors would like to acknowledge the EU project COST 541 'Thixosteel' and all their co-workers on that project for stimulating discussions.

\section{REFERENCES}

[1] Spencer D. B., Mehrabian R., Flemings M. C., Metall Trans., 3:1925-32, 1972.

[2] Young K. P., Riek, R. G., Flemings M. C., Metals Technology, 6:130-137, 1979.

[3] Kirkwood D.H., European patent No. 0305375 Thixotropic materials, 1988.

[4] Leatham A., Ogilvy A., Chesney P., Wood J. V., Metals and Mater., 5:140-3, 1989.

[5] Boyed L. E., Kirkwood D. H., Sellars C. M., In: Proc. $2^{\text {nd }}$ World Basque Congress on New Structural Materials, Spain, 285-95, 1988 (Publ. Vitoria Gasteiz).

[6] Kapranos P., Kirkwood D. H., Sellars C. M., Proc. Instn Mech Engrs Part B: J. of Engineering Manufacture, 207:1-8, 1993.

[7] Kapranos P., Gibson R. C., Kirkwood D. H., Hayes P. J., Sellars C. M., Mater. Sci. \& Technol., 12:2748, 1996.

[8] Prange R., Neuschutz D., In: Proc. $5^{\text {th }}$ Int. Conf. Semi-Solid Processing of Alloys and Composites, Bhasin A K, Moore J J, Young K P, Midson S, (ed.), publ. Colorado School of Mines, 653-60, 1998.

[9] Meyer S., Bleck W., op. cit. [8] 361-9.

[10] Cabeza M. M., Verdeja J. I., Pero-Sanz J. A., Plaza D., In: Proc. $30^{\text {th }}$ Annual Technical Meeting of the 
International Metallographic Society, Seattle, WA, Publ. ASM International, 425-8, 1997.

[11] Kim K B, Lee H. I., Moon H. K., op. cit. [8] 415-22.

[12] Song R., Kang Y., Zhao A., J. Mater. Process. Technol., 198:291-9, 2008.

[13] Walmag G., Naveau P., Rassili A., Sinnaeve M., In: Proc. $10^{\text {th }}$ Int. Conf. Semi-Solid Processing of Alloys and Composites, Hirt G., Rassili A., BuhrigPolaczek A. (editors), publ. Trans Tech Publications Ltd., Solid State Phenomena 141-143:415-20, 2008.

[14] Seidl I., Kopp R., Steel Res. Int., 75:545-51, 2004.

[15] Hirt G., Shimahara H., Seidl I., Kuthe F., Abel D., Schonbohm A., CIRP Annals-Manufacturing Technology, 54:257-60, 2005.

[16] Ramadan M., Takita M., Nomura H., El-Bagoury N., Mater. Sci. \& Engng. A, 430:285-91, 2006.

[17] Pahlevani F., Nili-Ahmadabadi M., Int. J. Cast Metals Research, 17:157-61, 2004.

[18] European Patent 0745694A1, Method and apparatus of shaping semisolid metals, UBE Industries, 1996.

[19] Haga T, Kouda T, Motoyama H, Inoue N, Suzuki S., In: Proc. ICAA7, Aluminium Alloys: Their Physical and Mechanical Properties, Vol. 1:327-32, 1998.

[20] Milostean D. C., Ioan I., Metalurgia International, 13:49-54, 2008.

[21] Ruys A. J., Kerdic J. A., Sorrell C. C., J. Mater. Sci., 31:4347-55, 1996.

[22] Bulte R., Bleck W., Steel Res. Int., 75:588-92, 2004.

[23] Omar M. Z., Atkinson H.V., Palmiere E. J., Howe A. A., Kapranos P., Steel Res. Int., 75:552-60, 2004.

[24] Omar M Z, Palmiere E J, Howe A A, Atkinson H V, Kapranos P, Mater. Sci. Engng. A, 395:53-61, 2005.

[25] Kazakov A. A., Adv. Mater. Process., 3:31-4, 2000.

[26] Fraipont C., Lecomte-Beckers J., op. cit. [13] 523-7.

[27] Lecomte-Beckers J., Rassili A., Robelet M., Poncin C., Koeune R., In: Proc. $9^{\text {th }}$ Int Conf. Semi-Solid Processing of Alloys and Composites, Kang C. G., Kim S. K., Lee S. Y. (ed.), publ. Trans Tech Publications, Solid State Phenomena 116-117:54-7, 2006.

[28] Robelet M, Rassili A, Fischer D, op. cit. [27] 712-6.

[29] Puttgen W, Bleck W, Steel Res. Int,75:531-6, 2004.

[30] Puttgen W., Hallstedt B., Bleck W., Uggowitzer P. J., Acta Mater., 55:1033-42, 2007.

[31] Hallstedt B., Baltichev E., Shimahar H., Neuschutz D., ISIJ International, 46:1852-7, 2006.

[32] Li J Y, Sugiyama S., Yanagimoto J., Chen Y L., Fan G W, J. Mater. Process. Technol. 208:165-70, 2008.

[33] Atkinson H. V., Prog. Mater. Sci., 50:341-412, 2005

[34] Modigell M., Pape L., Maier H R. op. cit.[27] 606-9.

[35] Cezard P, Favier V., Bigot R., Proc. $10^{\text {th }}$ ESAFORM Conf., AIP Conf. Proc. 907:1149-54, 2007.

[36] Omar M. Z., Atkinson H. V., Palmiere E. J., Howe A. A., Kapranos P., op. cit. [27] 677-80.

[37] Li J. Y., Sugiyama S., Yanagimoto J., J. Mater. Process. Technol., 161:393-406, 2005.

[38] Shimahara H., Baadjou R., Kopp R., Hirt G., op. cit. [27] 189-92.

[39] Solek K P., Mitura Z., Karbowniczek, M., Kapranos P., Kuziak R., Dutkiewicz J., op. cit. [13] 325-30.
[40] Kang Y. L., Song R. B., Li J. G., Zhao A. M., In: Proc. $5^{\text {th }}$ Pacific Rim Int. Conf. On Advanced Materials and Processing, Materials Science Forum, Parts 1-5, 475-479:2579-82, 2005.

[41] Ahmed R., Marc R., Regis B. (In fact this paper has been referenced incorrectly on Web of Science and should have as authors Rassili A., Robelet M., Bigot R.,) op. cit. [13] 213-8.

[42] Schonbohm A, Gasper R, Abel D, op. cit.[27]734-7.

[43] Behrens BA, Fischer D, Rassili A, op. cit.[13]121-6.

[44] Rassili A, Robelet M, Fischer D, op. cit. [27]717-20.

[45] Baadjou R., Knauf F., Hirt G., op. cit. [13] 37-42.

[46] Cezard P., Bigot R., Becker E., Mathieu S., Pierret J. C., Rassili A., op. cit. [35] 1155-60.

[47] Kuthe F., Schonbohm A., Abel D., Kopp R., Steel Res. Int. 75:593-600, 2004.

[48] Siegert K, Messmer G, op. cit. [47] 601-6.

[49] Lugscheider E., Hornig T., Kopp R., Kallweit J., Moller T., Adv. Engng. Mats., 3:998-1001, 2001.

[50] Kurapov D., Schneider J. M., op. cit. [47] 577-80.

[51] Behrens BA, Haller B, Fischer D, op. cit. [47]561-8.

[52] Kopp R., Shimahara H., Schneider J. M., Kurapov D., Telle R., Munstermann S., Lugschneider E., Bobzin K., Maes M., op. cit. [47] 569-76.

[53] Munstermann S., Telle R., Material Wissenschaft und Werkstofftechnik 37:324-8, 2006.

[54] Bobzin K., Lugscheider E., Maes M., Immich P., op. cit. [27] 704-7.

[55] Brabazon D, Naher S, Biggs P., op. cit. [13] 255-60.

[56] Birol Y, Ironmaking \& Steelmaking, 36:555-60, 2009.

[57] Birol Y., Steel Res. Int. 80:165-71, 2009.

[58] Birol Y., Steel Res. Int., 80:588-92, 2009.

[59] Puttgen W., Pant M., Bleck W., Seidl I., Rabitsch R., Testani C., Steel Res. Int. 77:342-8, 2006.

[60] Muenstermann S., Uibel K., Tonnesen T., Telle R., J. Mater. Process. Technol., 209:3640-9, 2009.

[61] Puttgen W., Bleck W., Hirt G., Shimahara H., Adv. Engng. Mats., 9:231-245, 2007.

[62] Uhlenhaut D. I., Kradolfer J., Puttgen W., Loffler J. F., Uggowitzer P. J., Acta Materialia, 54: 2727-34, 2006.

[63] Dziallach S., Puettgen W., Bleck W., op.cit.[13]695700.

[64] Munstermann S., Telle R, op. cit. [57] 171-6.

[65] Omar M. Z., Atkinson H. V., Kapranos P., Jaharah A. G., op. cit. [35] 1185-90.

[66] Rassili A., Pierret J. C., Vaneetveld G., Cezard P., Bigot R., Robelet M., op. cit. [13] 689-94. 